\section{ECONOMICS}

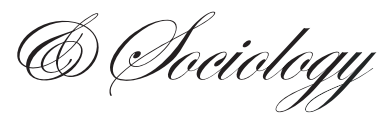

\author{
Eugenija Martinaitytè \\ Faculty of Economics and Finance \\ Management \\ Mykolas Romeris Univerity \\ Lithuania \\ E-mail:eu2martin@yahoo.com
}

\author{
Rusnè Kregždaitè \\ Mykolas Romeris University \\ Lithuania \\ E-mail: \\ rusne.kregzdaite@gmail.com
}

Received: January, 2015

1st Revision: February, 2015

Accepted: May, 2015

DOI: 10.14254/2071-

789X.2015/8-1/5

\title{
THE FACTORS OF CREATIVE INDUSTRIES DEVELOPMENT IN NOWADAYS STAGE
}

\begin{abstract}
.
Purpose. This paper analyzes factors most influencing development of creative industries (CI) in Lithuania in the context of the importance of this sector for the whole economy, using factors analysis and developing integrated CI factors assessment model.

Methodology. The theory of creative industries does not have a systemic approach to the creative industries' description. There is a lack of consolidated methodology on creative industries' impact assessment on the economy. Research factors were analyzed using methods of qualitative comparative analysis, which was made by Tosmana software. Method lets to indicate factors' influence on creative industries development and give recommendations about priority to strengthen factors with high and medium influence in order to use all the economic and social opportunities for creative industries sector development.
\end{abstract}

Findings. The factors analysis results show, that the high weight factors are: i) private expenditures for culture and ii) creativity index. These factors have a strong correlation coefficient also. The increasing these factors in Lithuania and Estonia are long-run objectives because of linkage to an educational system. Factors with medium influence are: government expenditures for culture, number of patents, and employment rate in $\mathrm{R} \& \mathrm{D}$ and tolerance index. Low weight influence factors are: employment in Creative Industries (CI), export of CI sector's production, government expenditures for R\&D and inhabitants with high education. A factor with no influence on economy growth is participation in cultural activities.

Research limitations. Performing the research it was taken into account several assumptions: the definition of Creative Industries (CI) used in the research based on UNCTAD's 2010 report. It was used to develop statistical scoring model of Lithuanian creative industries. The narrow range of variable used for the modeling caused by an absence of relevant statistical data. The data consists of 12 indicators, divided into four groups: Economic, Technological, Social and Cultural factors. The model can be expanded to incorporate additional internal and external factors.

Practical implications. The developed model targeted to assess Creative Industries' impact on the economy may be used to identify opportunities and priorities for strengthening certain areas (sub-sectors) of Creative Industries. An integrated assessment method lets to analyze which factors have high values in leading countries and by comparing it with Lithuania to find factors that used in these countries in order to support influences of creative industries sector in Lithuania.

Novelty. The integrated statistical assessment model for the Creative Industries impact on economy growth in Lithuania is newly developed.

Keywords: creative industries, economy development, factors, added value.

JEL Classification: C52, F43, L82, Z10 


\section{Introduction}

Creative industries can be defined as the area of overlap between culture, technology, science, and commerce. They involve the supply of goods and services that contain a substantial element of artistic and intellectual activities associated with a vital role in social and human development. It is the exceptional challenge to watch the process how the creative industries are fighting for the place in the economic theory and the reality. From the controversy in meanings of Creative industries (CI), till dimension in its evaluation criteria and lack of the measuring methodology, the assessment of the group of factors influencing the CI development is the useful analysis.

The growing importance of the Creative Industries for the economy development based on shifting in the communication technology and social liberalization within globalization process. According to the Creative Economy Report 2010,UNCTAD/UNDP: "Global exports of creative goods and services" products such as arts and crafts, audiovisuals, books, design work, films, music, new media, printed media, visual and performing arts, and creative services,more than doubled between 2002 and 2008. The total value of these exports reached US \$592 billion in 2008, and the growth rate of the industry over that six-year period averaged $14 \%$." The creative industries have grown at a significantly faster rate than the aggregate indicators of the world economy shows.

According to UNESCO report 2013 "The creative economy is now one of the most rapidly growing sectors of the global economy. It is also a highly transformative one in terms of income generation, job creation, and export earnings. Figures published in the UNCTAD Creative Economy Reports, 2008, 2010 show "that the creative economy has become an even stronger driver of development: World trade of creative goods and services totaled a record US\$ 624 billion in 2011, more than doubling between 2002 and 2011. The average annual growth rate of the sector during that period was 8.8 percent, and the exports of creative goods were even stronger in developing countries, averaging 12.1 percent annually over the same period". Between 2008 and 2011, employment in the cultural and creative sectors proved more resilient than in the EU economy as a whole with growth rates varying however between subsectors. This tendency is all the more interesting because some sectors have a higher percentage of youth employment than the rest of the economy.

Following the importance of Creative Industries mentioned above, the subject of research is a scope of factors influencing the Creative Industries, and the problem focusing on this study is: what is a level of factors' impact on the development of this economy sector- Creative Industries?

The aim of the paper is- to investigate the scope of factor influencing the development of Creative Industries.

The methods of the research. A systemic analysis of theoretical insights and practical applications developed by foreign and local authors, and comparative, logical and statistical analysis were used for the research.

\section{Main aspects of creative industries and their measurement}

The Creative Industries (CI) are the part of the economy as a social reality, and due to the absence of clear structure of productions and services belong to this sector, the studies are covering numerous aspects of CI without standard methodology for measuring CI effects on economy and investigating inputs on CI development. Wide range of research in this area shows the importance CI for private and social benefit and economy growth using innovative and knowledgeable factors. 
The concept Creative Industries contents verity of sideways as the field of research depends on the environment, segmentation, econ-social stage, and development. There are no finalized interpretation of CI concept; therefore we used following points to identify the stages of CI evolution. There are two directions of the CI modeling: from the Demand towards providers, and from initiatives /ideas/product' Providers towards markets/consumers. Some studies made efforts to combine different approach on principal characteristics of creativity, creative industries, and other related phenomena. According to KEA, 2006 the definition of creativity should define the area as Scientific creativity, Technological creativity, Economic Creativity and Cultural creativity entirely inter-depended within the Economy. UNSTAD proposed to classify CI by groups (heritage, arts, media functional creation). One direction of the CI modeling focused on CI impact on economy growth, and another direction - the scope of factors influencing as a driver for the CI development, which is a matter of the current paper.

Initially Framework for Cultural Statistics (FCS) proposed by UNESCO was adopted by various national institutions with to the specific cultural realities of their country. The FCS defines ten distinct categories: (0) cultural heritage; (1) printed matter and literature; (2\& 3 ) music and the performing arts; (4) visual arts; (5\&6) audiovisual media (5 cinema and photography; 6 radio and television); (7) socio cultural activities; (8) sports and games; (9) environment and nature. The framework also proposes cross-category matrices such as creation/ production, transmission/ dissemination, consumption, registration/protection and participation (UNCTAD,2008)..

The segmentation of Creative Industry (CI) sectors into Content and Service sectors proposed by UNCTAD and used for different purposes (Table 1).

Table 1.Creative Industries by segments.

\begin{tabular}{|c|c|c|c|}
\hline \multicolumn{4}{|c|}{ Creative Industries } \\
\hline HERITAGE & ARTS & MEDIA & $\begin{array}{l}\text { FUNCTIONAL } \\
\text { CREATIONS }\end{array}$ \\
\hline $\begin{array}{l}\text { Traditional cultural } \\
\text { expressions }\end{array}$ & Visual arts & $\begin{array}{l}\text { Publishing and printing } \\
\text { media }\end{array}$ & Design \\
\hline Art crafts & Paintings & Books & Interior \\
\hline Festivals & Sculpture & Newspapers & Graphic \\
\hline Celebrations & $\begin{array}{l}\text { Antique } \\
\text { Photography, etc. }\end{array}$ & Press and other publications & $\begin{array}{l}\text { Fashion } \\
\text { Jewellery } \\
\text { Toys }\end{array}$ \\
\hline Cultural sites & Performing arts & Audio-visuals & Creativity services \\
\hline Historical monuments & Live music & Film & Architecture \\
\hline Museums & Theater & Television \& radio & Advertising \\
\hline Libraries & Dance & Broadcasting & Creative R\&D \\
\hline \multirow[t]{5}{*}{ Archives, etc. } & Opera & New media & Cultural services \\
\hline & Puppetry & Digitized content & Digital services, etc \\
\hline & Circus, etc. & Software & \\
\hline & & Video games & \\
\hline & & Animations, etc. & \\
\hline
\end{tabular}

Source: UNCTAD, 2008. 


\section{Factors, influencing the development of creative industries}

Because of the relation to social and cultural activities, creative industries leads to economic development and the dynamics of a socio, political, cultural and economic processes. There are numbers of different definitions, typologies and classifications of the creative industries, and it means that creative sector is a growing economic domain with a valuable contribution to the local economy and significant job creation potential (Hui, 2007). The term creative industries encompass a broader range of activities that include the cultural industries, as well as all cultural or artistic production, whether live or produced as an individual unit. These industries are those in which the product or service contains a substantial element of artistic or creative endeavour and include activities such as architecture and advertising. (Understanding Creative Industries: Cultural statistics for public-policy making, UNESCO, 2006).

Creative industries are significant sector for economic growth and development not just in sense of adding jobs or expanding economic activity but also for the role in facilitating economic evolution by contribution to behavior, social and institutional evolution (Potts, 2011). Culture, as shared values, can affect efficiency, equity or determination of economic and social objectives. All this effects from individual will aggregate in collective outcomes and influence macroeconomic outcomes such as GDP, technological performance, employment, structural changes, income and social welfare programmes (Throsby, 2010).

The creative industries effects on total economy growth through economic, social, technology, scientific and cultural, and other multidimensional variables, therefore it is important to measure the impact of creativity. The economic growth depends on human capital, ability to attract a "creative class" and to perform that advantage in the form of new ideas and regional growth. The tool to indicate these capacities is a creativity index - the baseline indicator of creative economy' ability to perform. It can be used for measurement of region's long-run economic creativity trends as reflection of joint effects of "creative class" concentration and innovative economic outcomes (Florida, 2002). As any other sector, a creative industries sector is closely related to conditions of domestic economic system. The GDP growth, personal income rate, unemployment rate (Getzner, 2002), interest rate, price indexes, subsidies from the state, - all these factors are influencing the creative sector as well as any other economic activity. Creative industries are also linked to the production in the context of social development and because of a complexity of economic factors mentioned above it is difficult to explain sectors' development by separate factors. Creative industries are developed from the cultural sector, which is based on art activity, local culture and local economic welfare, social values, etc. Cultural industries mainly converged into creative industries, and in this case well-being indicators, such as happiness index become important factors (Tubadji et al., 2014). The studies are focusing on specific factors influencing creative industries' development as location, structure of creative industries, environment, inter-sectorial analysis and others. This research describes the influence of aggregate groups of factors on creative industries without specific segmentation.

The groups of factors called " 3 T's system" contain the aggregate categories of factors developed by R. Florida (2002), and they are following: Technology, Talent and Tolerance, which represented symbiosis creativity and economic development. All these factors have significant influence to creativity and creative industries sector, with aftermath effect on the economy.

First T: Technology is widely accepted factor for economic growth and changes in technologies are a key feature of it. The understanding of the importance of technological development is an important feature in almost every sector and branches. Countries' technological capacities can be measured by number of patents, spending for R\&D and employment in R\&D sector, productivity.

Second T: Talent also agrees key factor. Knowledge, creativity and creation of new ideas are essential for successful development and these features are arising from talented people 
(Martin Prosperity Institute, 2010). Talent is a feature that is difficult to measure and it could be analyzed by simultaneously study of few indicators or indexes such as high education, innovation indexes and share of creative class, which shows new tendencies in professional and personal environment. Complimentary index for talent measure is creative vitality index (CVI) developed in USA, which includes community participation and employment in the creative sector (Tubadji et al. 2014). Cultural involvement and spending are affected by age structure of the population (Benito et al. 2013). Talent also can be influenced by a greater number events and easier access to cultural activities.

Third T: Tolerance factor is mostly discussing and hardly accepted by economists. The Tolerance factor is most critical to region's ability to attract and mobilize creative talent (Florida, 2002). Places that are most open to new ideas and that attract talented and creative people from across the globe broaden both their technology and talent capabilities, thereby gaining a substantial economic edge. Tolerance is measured by identifying openness to new cultures, races, immigrants and other minorities. These factors can be classified according J. Potts theory of creative industries and economic evolutions (Potts, 2009) as presented in Table 2.

Table 2. Classification of factors, influencing creative industries

\begin{tabular}{llll}
\hline $\begin{array}{c}\text { Investment and supply } \\
\text { of input factors }\end{array}$ & $\begin{array}{c}\text { Qualitative improvement } \\
\text { of input factors }\end{array}$ & Growth of demand & $\begin{array}{c}\text { Institutional change and } \\
\text { efficiency }\end{array}$ \\
\hline Subsidies from the state & Education & Cultural participation & $\begin{array}{l}\text { Greater number of } \\
\text { cultural activities }\end{array}$ \\
\hline Interest rate & R\&D & $\begin{array}{l}\text { Age and structure of } \\
\text { demand }\end{array}$ & $\begin{array}{l}\text { Easies access of cultural } \\
\text { activities }\end{array}$ \\
\hline Price indexes & Patents & Education & Tolerance \\
\hline Unemployment rate & Innovation index & Income rate & \\
\hline GDP growth & & & \\
\hline
\end{tabular}

Source: own compilation based on (Potts, 2009).

John Howkins (2002) and Richard Florida (2003) pointed the emergence of a creative economy. There is a strong link between creativity and innovation and productivity growth, as a key driver of the economy's growth potential, competitiveness and economic and social wealth. The creative industries are possess strong innovation potentials by themselves, and they also influence the innovative processes and knowledge-based growth in other economic fields, affecting value added chains horizontally and vertically as suppliers and customers.

\section{Overview of the factors affecting the creative industries in most developed countries}

The classification and measuring of the Creative Industries are explored by world organizations as United Union, UNCTAD, and The European Creative Industries Alliance Policy Learning Platform. The primary classification systems of Creative Industries are: UK Standard Industrial Classification of Economic Activities (SIC); The Eurostat system (NACE); the UNCTAD classification based on EBOPS code. The creative industries include the following sub-sectors: music, performing arts; film, television and radio; advertising and marketing; software development and interactive content; writing, publishing and print media; and architecture, design and visual arts.

This study focuses on factors affecting add value of creative industries without splitting Creative industries into sub-sectors. 
The measurement methods of Creative industries development combine different indicators related to a particular type of production and specific feature of creativity. Most validated factors are employment within the industry; time use; trade and value added; copyright and intellectual property rights issues; public investment.

In order to find the most efficient way to effect the development of creative industries, the research relies on analysis of factors, which are influencing level of creative industries. The main indicator of creative industries development is the value added in creative industries sector (percentage of gross domestic product). Formally the creative industries are not classified as a unique unit in NACE 2 classificatory. By this reason this research based on creative industries sector data composed of following NACE 2 activities:

- J58 (Publishing activities),

- J59_J69 (Motion picture, video, television programme production; programming and broadcasting activities),

- M71 (Architectural and engineering activities; technical testing and analysis),

- M73 (Advertising and market research),

- R90_R92 (Creative, arts and entertainment activities; libraries, archives, museums and other cultural activities; gambling and betting activities),

- R93 (Sports activities and amusement and recreation activities).

According to the indicator of value added in creative industries sector, ten leading European Union countries were selected in order to compare their creative industries development with the same factors from Lithuanian and Estonian economies (Table.3).

Table 3. Added value in creative industries

\begin{tabular}{|l|c|}
\hline \multicolumn{1}{|c|}{ Country } & Added value in CI (percentage of GDP), 2012 \\
\hline Sweden & 5,934 \\
\hline United Kingdom & 5,411 \\
\hline Spain & 4,934 \\
\hline Finland & 4,820 \\
\hline Slovakia & 4,746 \\
\hline Germany & 4,60 \\
\hline Latvia & 4,543 \\
\hline France & 4,481 \\
\hline Denmark & 4,472 \\
\hline Slovenia & 4,368 \\
\hline Estonia & 3,433 \\
\hline Lithuania & 2,889 \\
\hline
\end{tabular}

Sourse: Eurostat, 2013

Add value is most important indicator for economy development and structural competiveness. As it illustrated in the Table 3 on the top of selected countries are Sweden and UK with accordingly 5.9 and 5.4 person input to GDP. Another group with interval 4 to 5 percents of GDP consists of most advanced European countries, and the last group with a share below 4 percent - Estonia and Lithuania. The changes in add value during the decade shown in Annex 1. Creative industries in all selected countries was strongly affected by crises 2007-2009; the recovery demonstrate how important this sector of all economy. It could be compared with added value in some real economy sectors (Table 4). 
RECENT ISSUES IN ECONOMIC DEVELOPMENT

Table 4. Total added value by sectors in Baltic countries, Sweden, Finland in 2000, 2010 (\%)

\begin{tabular}{|c|c|c|c|c|c|c|c|}
\hline Sector & Sweden & Finland & LT & LV & $\mathrm{EE}$ & ES-15 & ES-27 \\
\hline \multicolumn{8}{|l|}{ Agriculture } \\
\hline 2000 & 2.10 & 3.50 & 5.50 & 4.60 & 4.70 & 2.40 & 2.30 \\
\hline 2010 & 1.90 & 2.90 & 3.40 & 4.10 & 3.50 & 1.70 & 1.70 \\
\hline Change, $\%$ & -9.52 & -17.14 & -38.18 & -10.87 & -25.53 & -29.17 & -26.09 \\
\hline \multicolumn{8}{|l|}{ Manufacturing } \\
\hline 2000 & 24.50 & 28.40 & 24.60 & 17.70 & 22.50 & 21.80 & 21.80 \\
\hline 2010 & 21.10 & 22.30 & 22.10 & 16.70 & 23.10 & 18.60 & 18.70 \\
\hline Change, $\%$ & -13.88 & -21.48 & -10.16 & -5.65 & 2.67 & -14.68 & -14.22 \\
\hline \multicolumn{8}{|l|}{ Construction } \\
\hline 2000 & 5.50 & 6.60 & 5.90 & 5.60 & 5.60 & 5.70 & 5.70 \\
\hline 2010 & 4.30 & 6.20 & 5.60 & 5.00 & 5.80 & 5.90 & 6.00 \\
\hline Change, $\%$ & -21.82 & -6.06 & -5.08 & -10.71 & 3.57 & 3.51 & 5.26 \\
\hline \multicolumn{8}{|l|}{ Services } \\
\hline 2000 & 19.50 & 19.80 & 30.90 & 34.40 & 28.10 & 21.2 & 21.7 \\
\hline 2010 & 18.90 & 20.20 & 33.20 & 30.10 & 25.60 & 20.50 & 20.80 \\
\hline Change, $\%$ & -3.08 & 2.02 & 7.44 & -12.50 & -8.90 & -3.30 & -4.15 \\
\hline \multicolumn{8}{|c|}{ Financial intermediaries } \\
\hline 2000 & 24.60 & 24.20 & 12.20 & 18.70 & 22.60 & 26.80 & 26.50 \\
\hline 2010 & 24.90 & 21.00 & 16.00 & 23.50 & 24.20 & 29.30 & 29.00 \\
\hline Change, $\%$ & 1.22 & -13.22 & 31.15 & 25.67 & 7.08 & 9.33 & 9.43 \\
\hline \multicolumn{8}{|l|}{ Other sectors } \\
\hline 2000 & 27.40 & 24.20 & 21.00 & 19.90 & 15.70 & 22.00 & 22.10 \\
\hline 2010 & 25.30 & 20.70 & 19.60 & 19.70 & 18.60 & 24.10 & 23.70 \\
\hline Change, $\%$ & -7.66 & -14.46 & -6.67 & -1.01 & 18.47 & 9.55 & 7.24 \\
\hline Total & 100 & 100 & 100 & 100 & 100.00 & 100 & 100 \\
\hline
\end{tabular}

Sourse: Eurostat, National Accounts (2008, 2012), OECD Report $(2008,2012)$.

The changes of value added in creative industries sector in most well developed countries (except Sweden, United Kingdom and Latvia) are very similar; vary around $4-5$ percent (Figure 1). The value added in Lithuania and Estonia is in average 1 (in Lithuania) - 1, 5 (in Estonia) percent lower than the mean of above mentioned countries. There was a sharp decrease of value added during the economic crisis in Estonia and Lithuania and the average of selected best-rated countries remained steady during the period of 2002-2011.

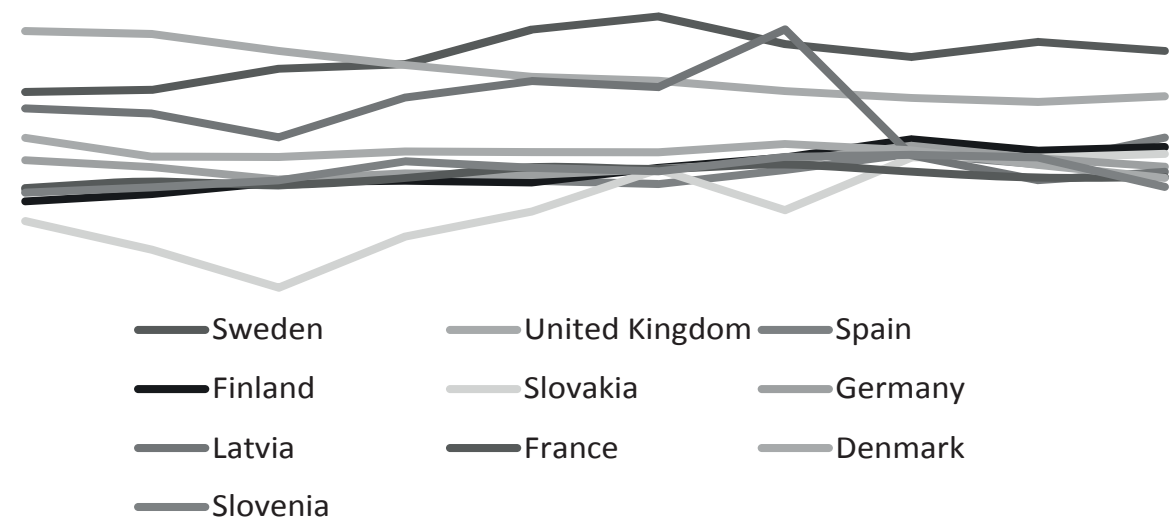

Figure. 1. Value added in creative industries sector

Sourse: Eurostat, 2012. 
As the data illustrated added value in creative industries (Table 4) similar to added value in the agricultural sector in Latvia, Lithuania, Estonia, and much higher in Sweden and Finland. It should be stressed, that creative industries are highly innovated.

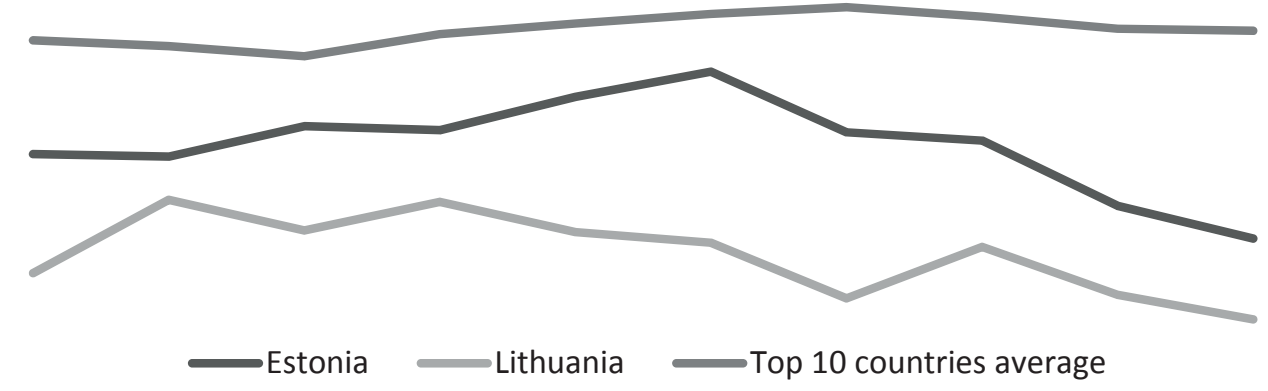

Figure. 2. Value added in creative industries sector in Lithuania and Estonia

Sourse: Eurostat, 2012.

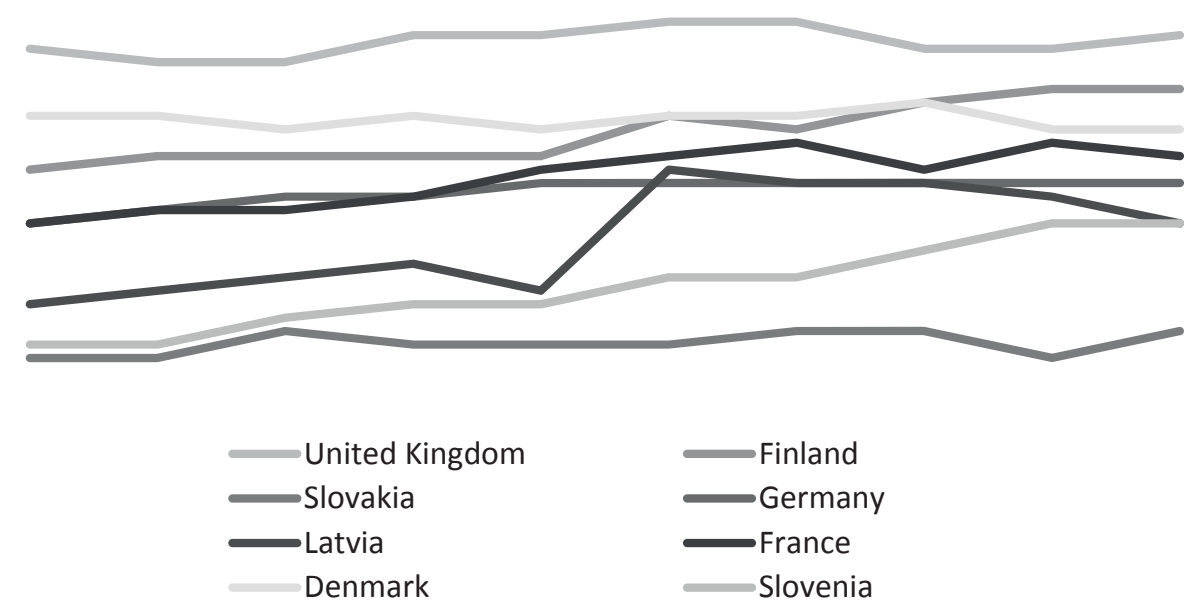

Figure. 3. Employment in creative industries sector (data from Sweden and Spain is not available) Sourse: Eurostat, 2012.

Employment in the creative industry is related to ability to transform creativity and creative ideas to activities, which are generating economic outcome. The employment rate in analyzed countries varies from 2, 9 to 5,9 percent of total employment. The employment growth is steady in all countries, except Latvia with the rise of 23 percent in 2007. Employment in creative industries sector in Estonia is similar to the previously selected countries average, Lithuania is around 1.0 percent point below the average, but this indicator is increasing, and it has comparatively high value. 


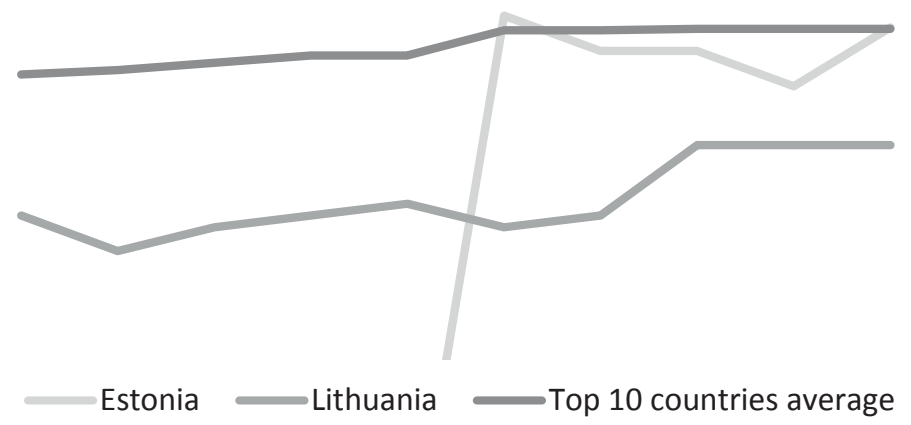

Figure. 4. Employment in creative industries sector in Lithuania and Estonia. (Data of Estonia available from 2007)

Sourse: Eurostat, 2012.

After the crisis 2007-2009 the unemployment in all Baltic countries remains in the 8-12 percent range, it is particularly high for youth. Therefore, the positive trends young people in creative industries growth show the need to support accessibility to creative industries. Between 2008 and 2011, the employment in the cultural and creative sectors proved more resilient than in the EU economy as a whole. There were growth rates differences between subsectors, and some sectors have a higher percentage of youth employment than the rest of the economy.

Export of creative industries products and services has from 0,5 to 4,5 percent in total export structure. The average of selected countries is not stable and there is a slight increase in recent years, and the meaning of this indicator is very different in each country. It could be partly explained by the content of the production and language barriers. The export of Lithuania and Estonia is greater than the selected countries average.

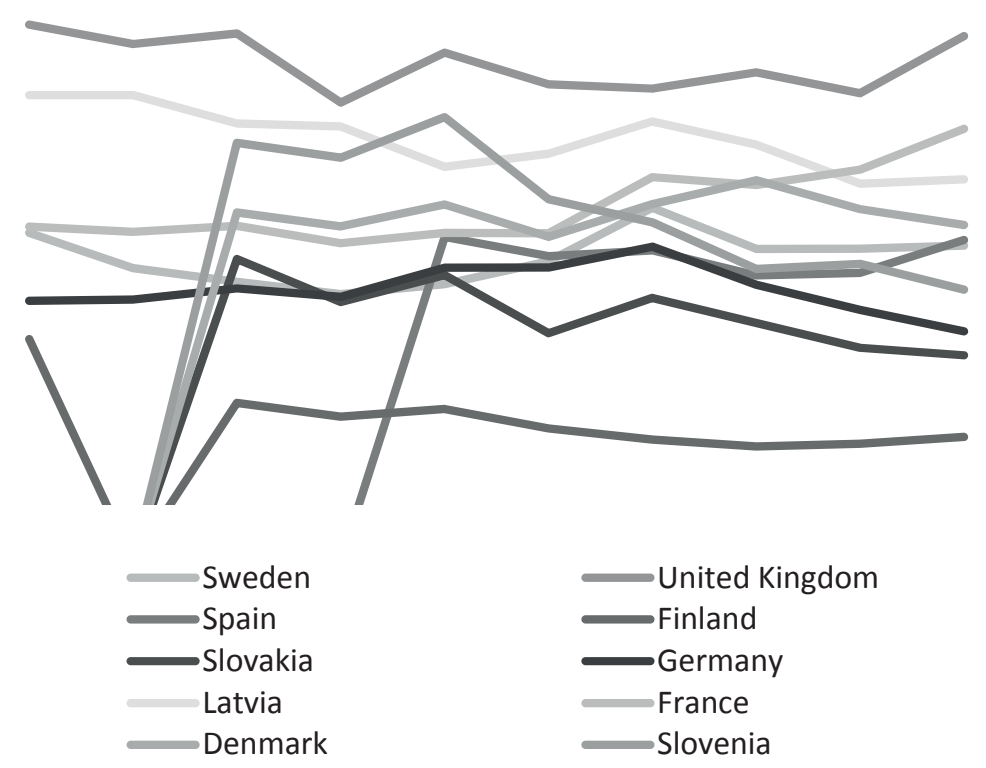

Figure. 5. Export in creative industries sector (as a share of total export).

Note. Data from Finland, Slovakia, Denmark and Slovenia available from 2004.

Sourse: Eurostat, 2012. 


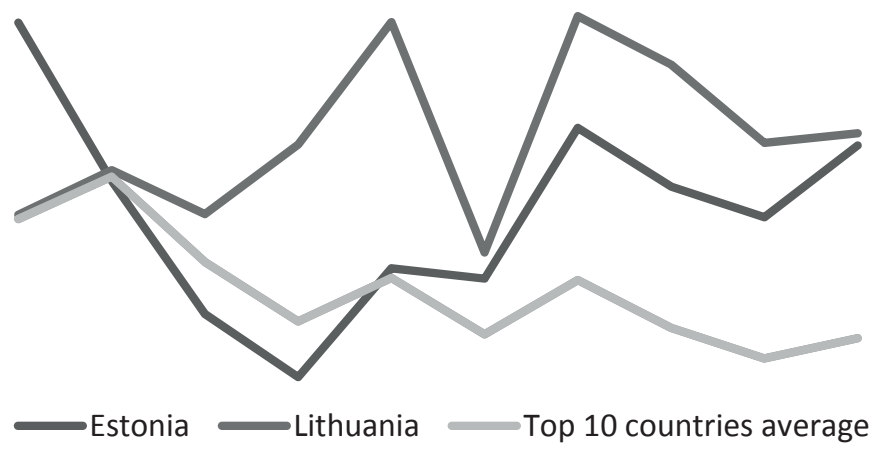

Figure 6. Export in creative industries sector (as a share of total export) of Lithuania and Estonia. Sourse: Eurostat, 2012.

Being at the crossroads of arts, business and technology, creative industries influence other industries IT applications, tourism. Creative industries are integrated at all stages of the value chain of other sectors such as fashion and high-end industries.

\section{Data and empirical analysis}

The empirical part of this paper uses a broad sample of selected countries. The full sample period covers the last decade from 2003 to 2013. As it was described above, the principal component analysis related to particular groups of factors influencing the creative industries development.

Four distinct factors groups were identified as primary affecting on creative industries. Each of which is briefly outlined below. Further analysis does not consist of time series analysis; data are available for the latest year. A group consists of 12 indicators, divided into four groups: Economic, Technological, Social and Cultural factors, which data are presented in Table 5. These groups are following:

Economic indicators

E1->Employment in CI (percentage of total), 2011

E2->Government expenditures for culture (percentage of total), 2011

E3-> Export of CI (percentage of total), 2011

\section{Technological indicators}

T1- Government expenditures for R\&D (percentage of total), 2011

T2- Number of patents for million inhabitants, 2011

T3- Employment in R\&D (percentage of total), 2011

\section{Social indicators}

S1- Inhabitants with high education (percentage of total), 2011

S2- Creativity index, 2011

S3-Tolerance index, 2010

\section{Cultural indicators}

C1-Students enrolled in arts \& humanities studies, 2011

C2- Participation in cultural activities, 2007

C3- Expenditures for culture and recreation, 2010

There are macro indicators by selected countries for the period 2002-2013. 
RECENT ISSUES IN ECONOMIC DEVELOPMENT

Table 5. Statistical data on the variables

\begin{tabular}{lccccccccccccc}
\hline & $\begin{array}{c}\text { Main } \\
\text { indicator }\end{array}$ & E1 & E2 & E3 & T1 & T2 & T3 & S1 & S2 & S3 & C1 & C2 & C3 \\
\hline Sweden & 5,934 & 0 & 1,1 & 2,666 & 3.38709 & n/a & 209.7135 & 31,4 & 0,923 & 7 & 13,5 & n/a & 3730 \\
\hline $\begin{array}{l}\text { United } \\
\text { Kingdom }\end{array}$ & 5,411 & 5,8 & 1 & 4,436 & 1.78145 & 0,4 & 240.1243 & 35,7 & 0,789 & 10 & 16,9 & n/a & 3211 \\
\hline Spain & 4,934 & 0 & 1,5 & 2,714 & 1.35563 & n/a & 73.4037 & 30,9 & 0,744 & 6 & 11 & 21 & 2049 \\
\hline Finland & 4,82 & 5,4 & 1,2 & 1,05 & 3.79677 & 0,7 & 304.0536 & 33,6 & 0,894 & 19 & 14,1 & 33 & 2806 \\
\hline Slovakia & 4,746 & 3,6 & 1,1 & 1,74 & 0.67915 & 0,4 & 41.39841 & 17,7 & 0,476 & 55 & 7,3 & 27 & 1077 \\
\hline Germany & 4,6 & 4,7 & 0,8 & 1,942 & 2.89286 & 0,4 & 572.8562 & 25,1 & 0,764 & 18 & 13,3 & n/a & 2993 \\
\hline Latvia & 4,543 & 4,4 & 1,6 & 3,226 & 0.69631 & 0,1 & 85.4817 & 27 & 0,52 & 60 & 8,9 & 17 & 742 \\
\hline France & 4,481 & 4,9 & 1,5 & 3,653 & 2.24979 & 0,8 & 223.4715 & 28,9 & 0,764 & 16 & 13,7 & n/a & 2132 \\
\hline Denmark & 4,472 & 5,1 & 1,6 & 2,841 & 2.97599 & 0,4 & 280.9396 & 29,1 & 0,878 & 14 & 12,8 & 25 & 3281 \\
\hline Slovenia & 4,368 & 4,4 & 1,9 & 2,295 & 2.47362 & 0,6 & 234.6003 & 23 & 0,638 & 51 & 8,5 & 22 & 2285 \\
\hline Estonia & 3,433 & 4,8 & 1,9 & 3,252 & 2.37073 & 0,3 & 46.96351 & 33,2 & 0,528 & 68 & 13,7 & 51 & 871 \\
\hline Lithuania & 2,889 & 3,8 & 1 & 3,289 & 0.91765 & 0,3 & 31.29306 & 29,8 & 0,484 & 75 & 7,4 & 22 & 574 \\
\hline
\end{tabular}

Sources: Eurostat, 2014

Several considerations guide the choice of methodology in this paper. The paper focuses simplicity, flexibility and robustness in its statistical assessment of the impact of volatility on growth creative industries. At the same time, given the complexity of the research problem restrictions imposed by limited sample scope, the issues of omitted variables is significant. To analyze the relation of creative industries factor to the primary indicator (value added in CI sector) their correlation coefficients were calculated for each of 12 indicators. Values are presented in Table 5. The most significant indicators for development of creative industries seem to be social and cultural variables, especially creativity, tolerance, participation in cultural activities and expenditures for culture. It substantiates one of the main hypotheses of creative industries sector which states that social and cultural variables and creativity the most important ones and have the indirect impact to the economic development and financial growth.

Table 6. Correlation matrix

\begin{tabular}{cccccccccccc}
\hline \multicolumn{10}{c}{ Correlation matrix with primary indicator (Value added in CI sector) } \\
\hline E1 & E2 & E3 & T1 & T2 & T3 & S1 & S2 & S3 & C1 & C2 & C3 \\
\hline 0.354 & -0.272 & -0.103 & 0.322 & -0.184 & 0.333 & 0.085 & 0.664 & 0.769 & 0.44 & 0.559 & 0.728 \\
\hline
\end{tabular}

Sources: own calculation

Table 7. Configurations for the analysis

\begin{tabular}{cccccccccccccc}
\hline \multicolumn{10}{c}{ Setter values for Boolean configurations (less -0, more -1$)$} \\
\hline $\begin{array}{c}\text { Main } \\
\begin{array}{c}\text { indicator } \\
\text { (result) }\end{array}\end{array}$ & E1 & E2 & E3 & T1 & T2 & T3 & S1 & S2 & S3 & C1 & C2 & C3 \\
\hline 3,69 & 4,48 & 1,05 & 2,51 & 2 & 0,35 & 187 & 28 & 0,62 & 10,2 & 25.01 & 1000 & 22 \\
\hline
\end{tabular}

Sources: own calculation

The Qualitative Comparative Analysis (QCA) procedure starts with specifying the significant causal conditions for the outcome variable the (primary indicator) and then by reducing 


\section{RECENT ISSUES IN ECONOMIC DEVELOPMENT}

complexity and transferring data in Boolean form. Software (in this case TOSMANA) calculates truth table that displays the data as a list of configurations (factors) which leads to the same output. Table 7 of settings lets to summarize data and describe cases in more synthetic way.

In order to find factors that influence the primary indicator of creative industries (the value added in Creative industries sector) factors analysis was made. Each indicator was transformed into Boolean form giving the value 1 if has high value and 0 if the value is low. The values of low and high refer to each indicator by sign of the group and analytical findings. These values are presented in Table 7. The Boolean configurations are shown in Table 8.

Table 8. Setter (Thresholds) values

\begin{tabular}{llllllllllllll}
\hline E1 & E2 & E3 & T1 & T2 & T3 & S1 & S2 & S3 & C1 & C2 & C3 & $\begin{array}{c}\text { Main indicator } \\
\text { (Result) }\end{array}$ & Country \\
\hline 0 & 1 & 1 & 1 & 0 & 1 & 1 & 1 & 0 & 1 & 0 & 1 & 1 & Sweden \\
\hline 1 & 1 & 1 & 1 & 1 & 1 & 1 & 1 & 0 & 1 & 0 & 1 & 1 & France, Denmark \\
\hline 1 & 0 & 1 & 0 & 1 & 1 & 1 & 1 & 0 & 1 & 0 & 1 & 1 & United Kingdom \\
\hline 1 & 0 & 0 & 1 & 1 & 1 & 0 & 1 & 0 & 1 & 0 & 1 & 1 & Germany \\
\hline 0 & 1 & 1 & 0 & 0 & 0 & 0 & 0 & 1 & 0 & 0 & 0 & 1 & Latvia \\
\hline 0 & 1 & 1 & 0 & 0 & 0 & 1 & 1 & 0 & 1 & 0 & 1 & 1 & Spain \\
\hline 0 & 1 & 0 & 1 & 1 & 1 & 0 & 1 & 1 & 0 & 0 & 1 & 1 & Slovenia \\
\hline 0 & 1 & 0 & 0 & 1 & 0 & 0 & 0 & 1 & 0 & 1 & 1 & 1 & Slovakia \\
\hline 1 & 1 & 0 & 1 & 1 & 1 & 1 & 1 & 0 & 1 & 1 & 1 & 1 & Finland \\
\hline 0 & 0 & 1 & 0 & 0 & 0 & 1 & 0 & 1 & 0 & 0 & 0 & 0 & Lithuania \\
\hline 1 & 1 & 1 & 1 & 0 & 0 & 1 & 0 & 1 & 1 & 1 & 0 & 0 & Estonia \\
\hline
\end{tabular}

Note: Constructed using the program TOSMANA.

Sources: own calculation

This method lets to analyze which factors have high values in leading countries and by comparing it with Lithuania and Estonia it allows to find factors, which should be strength in order to use the potential capacity of creative industries sector. The factor has a high value in the most countries, and it leads to a good result of the primary indicator. Therefore, these phenomena could be interpreted as necessary for the development of creative industries. In some countries the factor has a low value or high value, but the main indicator remains in a high position. In this case this factor does not have a significant influence on the creative industries development. The factors are divided into four groups according to their impact on the primary indicator. There should be a priority to strengthen high and medium influence factors in order to use all the economic and social development opportunities for the creative industries sector.

Table 9 Factors, according to their influence on Creative Industries sector

\begin{tabular}{|c|c|c|}
\hline High influence factors & $\begin{array}{l}\text { Medium influence } \\
\text { factors }\end{array}$ & $\begin{array}{c}\text { Low influence factors Factors with no influ- } \\
\text { ence }\end{array}$ \\
\hline $\mathrm{C} 3$ & E2 & E1 \\
\hline \multirow[t]{4}{*}{ S2 } & $\mathrm{T} 2$ & E3 \\
\hline & T3 & $\mathrm{T} 1$ \\
\hline & $\mathrm{C} 1$ & S1 \\
\hline & S3 & \\
\hline
\end{tabular}

Sources: own calculation. 


\section{Results and findings}

High influence factors are private expenditures for culture and creativity index. These factors have strong correlation coefficient as well. Increasing these factors in Lithuania and Estonia are long-run objectives because its linkage to the educational system.

Medium influence factors are government expenditures for culture, number of patents, the employment rate in R\&D, number of students enrolled in arts and humanities and tolerance index. Lithuania has low values for all of these factors; Estonia has high value in E2 and C1. Factor with highest correlation coefficient is tolerance index. It is proved that more open and tolerant communities easier accept changes and adapt to changing environment (Martin Prosperity Institute, 2011). The development of this index could lead to improvement of creative industries sector and economic growth.

Low influence factors are employment in CI, export of CI sector, government expenditures for R\&D and inhabitants with high education. Lithuania and Estonia have high values in most of these indicators, and it can be interpreted as investing to least important factors of creative industries development.

Table 10. Topology of factors influenced on Creative industries

\begin{tabular}{lll}
\hline Strong & $\begin{array}{l}\text { Category I } \\
\text { Expenditures for culture and cre- } \\
\text { ativity index }\end{array}$ & $\begin{array}{l}\text { Category II } \\
\text { Government expenditures for culture, number of } \\
\text { patents, employment rate in R\&D, number of stu- } \\
\text { dents enrolled in arts and humanities and tolerance } \\
\text { index. }\end{array}$ \\
\hline Week & $\begin{array}{l}\text { Category III } \\
\text { Employment in CI, export of CI } \\
\text { sector, government expenditures } \\
\text { for R\&D and inhabitants with high } \\
\text { education. }\end{array}$ & $\begin{array}{l}\text { Category IV } \\
\text { Not defined precisely }\end{array}$ \\
\hline
\end{tabular}

Sources: own work.

Factor with no influence is participation in cultural activities although it has a strong correlation with primary indicator. The reason for this misunderstanding could be missing values in data set as the data was taken from Adult education survey, and some of the countries did not provide data for it.

\section{Conclusions}

The key point to this analysis has been the beneficial role of creative industries in growth of the economy, and the rapid increase of the percentage of value added in GDP created by creative industries is in most advanced countries. The policy makers in Lithuania must increase state support for investment in creative industries research and technology innovation (through generation creative industries research centers). There is also an invitation to potential investors for support creative industries development initiatives.

The empirical evidence support the demand to strength creative industries development policy in Lithuania. Factors influencing the Creative industries are weak in Lithuania, and most important indicator of efficiency - value added to GDP is still behind of most European countries.

Results of factors analysis reveals that most important factors for creative industries development are private expenditures for the culture. The creativity index and values of these factors cannot be increased in a short-run; it requires changes in education system and cultural policy. 
In comparison with other countries, Lithuania and Estonia have a large percent of population employed in cultural sector. The analysis shows, that it is not important factor for the development of creative industries and in order to achieve results in this growing sector "quantity" should be replaced by "quality". That repeatedly confirms importance of education and creativity training.

This research could be continued on impact value chains, innovations and concentration of stakeholders within creative industries differs per sub-sector.

\section{References}

Benito, B., Bastida, F., Vincente, C. (2013), Municipal elections and cultural expenditure..Journal for cultural economics., 37(3):3-32.

Cotte Poveda, A., Pardo Martinez, C.I.(2013), Qualitative comparative analysis (QCA): an application for the industry. Quality \& Quantity., 47(3):1315-1321.

Florida, R. (2002), The rise of the creative class. New York: Basic books.

Florida, R. (2005), The flight of the creative class. New York: HarperCollins Publishers Inc.

Getzner, M. (2002), Determinants of public cultural expendiures: an exploratory time series analysis for Austria. Journal of cultural economics. 26(4):287-306.

Hartley, J. (2007), The evolution of the creative industries - Creative clusters, creative citizens and social network markets. In Proceedings Creative Industries Conference, Asia-Pacific Weeks.

Howkins, J. (2002), The Creative Economy: How People Make Money From Ideas. London: Penguin books.

Hui, D. (2007), The creative industries and entrepreneurship in East and Souteast Asia. Enterpreuneship in the Creative Industries. An International Perspective. Cheltenham: Edward Elgar Publishing Limited, p. 9-29.

Martin Prosperity Institute. (2010), Creativity and Prosperity: The Global Creativity Index. Toronto: Martin Prosperity Institute.

Norkus, Z. (2012), On Baltic Slovenia and Adriatic Lithuania. A Qualitative Comparative Analysis of Paterns in Post-communist Transformation.Vilnius: Apostrofa.

Norkus, Z; Morkevičius, V. (2011), Kokybinè lyginamoji analizė. Kaunas: Standartų spaustuvè.

Potts, J. (2011), Creative industries and economic evolution. Cheltenham, Edward Elgar Publishing Inc.

Potts, J. (2009), Why creative industries matter to economic evolution. Economics of Innovation and New Technology. 18(7-8): 663-673.

Rihoux,B; Grimm, H. (2006), Inovative Comparitive Methods for Policy Analysis. New York: Springer Science, Business Media Inc.

Throsby, D. (2010), Economics and culture. Cambridge: Cambridge University Press.

Tubadji,A; Osoba, B.J; Nijkamp,P.(2014), Culture-based development in the USA: culture as a factor for economic and social well-being at a country level. Journal of Cultural economics. [interactive] 38:4. [accessed 2014-09-30]. < http://link.springer.com/content/pdf/10.1007\%2Fs10824-014-9232-3.pdf>.

Eurostat. Adult education survey

http://epp.eurostat.ec.europa.eu/portal/page/portal/product_details/publication?p_product_code=KS$\mathrm{CC}-05-005>$

Eurostat. Education statistics. [interactive]. [accessed 2014-09-30].

$<$ http://appsso.eurostat.ec.europa.eu/nui/show.do?dataset=educ ilev\&lang=en>

Eurostat. Employment statistics. [interactive].[accessed 2014-09-30]. 


\section{RECENT ISSUES IN ECONOMIC DEVELOPMENT}

$<$ http://appsso.eurostat.ec.europa.eu/nui/show.do?dataset=lfsi_emp_aHYPERLINK "http://appsso.eurostat.ec.europa.eu/nui/show.do?dataset=lfsi_emp_a\&lang=en"\&HYPERLINK "http://appsso. eurostat.ec.europa.eu/nui/show.do?dataset=lfsi_emp_a\&lang=en"lang=en>

Eurostat. Government expenditures statistics. [interactive].[accessed 2014-09-30].

$<$ http://epp.eurostat.ec.europa.eu/portal/page/portal/statistics/search_database $>$

Eurostat. National accounts and main components. [interactive].[accessed 2014-09-30].

$<\mathrm{http}$ ://appsso.eurostat.ec.europa.eu/nui/show.do?dataset=nama_gdp_cHYPERLINK "http://appsso. eurostat.ec.europa.eu/nui/show.do?dataset=nama_gdp_c\&lang=en"\&HYPERLINK "http:// appsso.eurostat.ec.europa.eu/nui/show.do?dataset=nama_gdp_c\&lang=en"lang=en>

UNCTAD.(2008), Creative Economy report. [interactive]. [accesed 2014-09-10]

$<$ http://www.unctad.org/en/docs/ditc20082cer_en.pdf $>$.

World bank. Number of patents statistics [interactive].[accessed 2014-09-30]. <http://data.worldbank. org/indicator/IP.PAT.RESD> 


\section{RECENT ISSUES IN ECONOMIC DEVELOPMENT}

Annex 1.Value Added in Creative Industries sector

\begin{tabular}{lcccccccccc}
\hline \multicolumn{1}{c}{ GEO/TIME } & 2002 & 2003 & 2004 & 2005 & 2006 & 2007 & 2008 & 2009 & 2010 & 2011 \\
\hline Sweden & 5.46 & 5.48 & 5.73 & 5.78 & 6.18 & 6.33 & 6.01 & 5.86 & 6.04 & 5.93 \\
\hline United Kingdom & 6.16 & 6.13 & 5.93 & 5.77 & 5.64 & 5.59 & 5.47 & 5.39 & 5.35 & 5.41 \\
\hline Spain & 4.33 & 4.42 & 4.38 & 4.48 & 4.44 & 4.40 & 4.56 & 4.75 & 4.63 & 4.93 \\
\hline Finland & 4.20 & 4.29 & 4.42 & 4.44 & 4.42 & 4.59 & 4.71 & 4.92 & 4.79 & 4.83 \\
\hline Slovakia & 3.97 & 3.65 & 3.21 & 3.80 & 4.09 & 4.57 & 4.10 & 4.71 & 4.71 & 4.75 \\
\hline Germany & 4.68 & 4.60 & 4.45 & 4.52 & 4.50 & 4.57 & 4.66 & 4.84 & 4.70 & 4.60 \\
\hline Latvia & 5.27 & 5.21 & 4.94 & 5.40 & 5.59 & 5.52 & 6.18 & 4.73 & 4.45 & 4.54 \\
\hline France & 4.36 & 4.43 & 4.39 & 4.47 & 4.60 & 4.57 & 4.63 & 4.54 & 4.48 & 4.48 \\
\hline Denmark & 4.93 & 4.72 & 4.71 & 4.77 & 4.77 & 4.77 & 4.86 & 4.79 & 4.62 & 4.47 \\
\hline Slovenia & 4.30 & 4.36 & 4.44 & 4.66 & 4.59 & 4.55 & 4.71 & 4.74 & 4.71 & 4.37 \\
\hline Estonia & 4.00 & 3.98 & 4.19 & 4.16 & 4.39 & 4.56 & 4.15 & 4.09 & 3.65 & 3.43 \\
\hline Lithuania & 3.20 & 3.69 & 3.49 & 3.68 & 3.48 & 3.41 & 3.03 & 3.38 & 3.05 & 2.89 \\
\hline
\end{tabular}

Source: Eurostat. 